\title{
A Reassessment Of Regulated Bank Capital On Profitability And Risk
}

Charles Corcoran, University of Wisconsin - River Falls, USA

\begin{abstract}
Banks must maintain minimum capital levels, but a regulated balance sheet implies profit suboptimization. Moreover, the presumptive role of minimum capital in reducing insolvency risk may be misplaced. Evidence is presented that suggests a bank's level of capital may not accurately presage the risk of loan default. Regulators must exercise restraint in further increasing bank capital levels, as unintended consequences may make matters worse.
\end{abstract}

Keywords: bank, WACC, CAMELS

\section{INTRODUCTION}

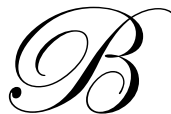

anking is undoubtedly one of the most regulated industries in the world and the rules on bank capital are one of the most prominent aspects of such regulation. This prominence results from the central role that banks play in financial intermediation, the importance of bank capital for bank soundness, and the efforts of the international community to adopt common bank capital standards. This influence was one of the key factors behind the international efforts to harmonize capital standards in the 1980s (Madura, 2007).

The increased number of bank failures over this past year has raised concerns about the riskiness of banks and, hence, prompted movements for tighter capital requirements. The Basel Agreement of 1988 requires that banks in the United States and in many European countries meet the minimum capital ratios of four percent tier 1 capital and eight percent tier 1 plus tier 2 capital to risk-weighted assets. ${ }^{1}$

${ }^{1}$ 'Tier 1 capital consists mainly of common stock and some perpetual preferred stock. Tier 2 capital includes preferred stock, subordinated debt, and allowance for loan losses. In calculating risk-weighted assets, assets are classified into four risk-weight categories; i.e. zero percent, 20 percent, 50 percent, and 100 percent risk-weight category. For example, most government securities fall into the zero risk-weight category, claims guaranteed by depository institutions are given 20 percent risk-weight, loans fully secured by first liens on residential properties are included in 50 percent risk-weight category, and most other loans fall into 100 percent risk-weight category. Risk weights are also applied to the credit-equivalent amount of off-balance-sheet items.

The capital requirement, which imposes constraints on the capital structure of banks, can affect the weighted average cost of capital (the average cost of equity and debt weighted by their proportions) and, hence, the investment decision of banks.

\section{LITERATURE REVIEW}

The well-known proposition of Modigliani and Miller (1958) show that the weighted average cost of capital (WACC) is independent of capital structure when the costs of equity and debt are determined in a frictionless market. In the banking sector, the cost of debt (deposits) is not determined by the market since deposits are insured. In addition, the cost of equity can deviate from market fundamentals when there is information asymmetry between managers and the stock market. Assuming that deposit financing is cheaper than equity financing due to underpriced deposit insurance premiums, using a higher proportion of equity increases the WACC. An increased weighted average cost of capital will reduce the number of profitable investment opportunities. In this case, the 
capital requirement limits the banks' ability to take advantage of the value derived from the deposit insurance, i.e., risk that is not reflected in the interest rate on deposits.

There is a second effect of the capital requirement that may unduly limit the growth potential of banks. Finance literature suggests that the cost of equity can be excessively high on occasion. The stock of a firm can be mispriced due to asymmetric information between the management of the firm and the stock market (Ting, 2005; Eden and Boyan, 1994). Managers are better informed about the future cash flow of the firm. Issuing shares at an unfavorable price (below the present value of the future cash flow estimated by managers) dilutes the value of existing shares. Assuming managers have favorable inside information and act in the interest of existing shareholders, they may pass up a good investment opportunity rather than issue shares to finance the investment.

Given this logic, the statutory capital requirement, which necessitates some equity financing, can restrain banks from pursuing profitable investment opportunities. In this case, banks may be handicapped by the capital requirement which limits the choice among financing alternatives. This effect of the capital requirement is not only undesirable but also disruptive. The investment decision of a bank may change with the degree of information asymmetry faced by the bank. Thus, in assessing the effects of the capital requirement, it is important to understand the role of asymmetric information.

The findings of previous studies generally support the presence of asymmetric information. They examine the investment behavior of commercial firms and find a positive relationship between the firms' cash flow from financing activities and investment [Fazzari et al.(1988) and Devereux and Schiantarelli (1990)]. The positive relationship, they argue, indicates the difficulty of external financing that may arise from asymmetric information. Since bank assets, loans in particular, are information intensive, information asymmetry is likely to be more serious in the banking sector than in many other industries producing standardized products. In addition, the effect of information asymmetry will be more pronounced when equity financing is necessary.

The financial distress that followed the implosion of markets for securitized mortgages in 2007 has raised profound doubts about the adequacy of the regulatory regime presently in place. In particular, the use of the CAMELS rating scheme, hereafter "CAMELS." The acronym stands for: capital adequacy, asset quality, management quality, earnings, liquidity, and sensitivity to market conditions. CAMELS is a U.S. supervisory rating of the bank's overall condition used to classify the nation's 8,500 banks. This rating is based on financial statements of the bank and on-site examination by regulators like the Fed, the OCC and FDIC. The scale is from 1 to 5 with 1 being strongest and 5 being weakest. These ratings are not released to the public but only to the top management of the banking company to prevent a bank run on a bank which has a bad CAMELS rating. This veil of secrecy may be misguided. Not that depositors would withdraw funds in reaction to a middling CAMELS score since their deposits are largely insured. But there is no evidence indicating a deposit outflows would be an undesirable outcome. A related, unanswered question is whether this disclosure would motivate bankers to "mind the shop" more wisely.

CAMELS is being used by the United States government in response to the global financial crisis of 2008 to help it decide which banks to provide special help for and which to not as part of its capitalization program authorized by the Emergency Economic Stabilization Act of 2008.

A cornerstone of the CAMELS is "C," capital adequacy. Capital ratios have long been a valuable tool for assessing the safety and soundness of banks. The informal use of ratios by bank regulators and supervisors goes back well over a century (Mitchell, 1909). In the United States, minimum capital ratios have been required in banking regulation since 1981, and the Basel Accord has applied capital ratio requirements to banks internationally since 1988.

\section{CAPITAL RATIOS AND THE LIKELIHOOD OF FAILURE}

A bank's Tier One Risk-Based Capital Ratio is a bank's common equity divided by its risk-adjusted assets. It is a key measure of a bank's ability to withstand future loan losses. A bank must maintain a ratio of six percent or more to be considered "well capitalized" by regulators. 
A bank's net charge-off ratio is the percentage of its loans that are written off as bad debts, less recoveries. A ratio of three percent or more is considered too high. A significant negative relationship between the capital ratio and the charge-off ratio should be expected. That is, a bank with a high capital ratio is presumably in a conservative financial posture. The charge-off ratio for such an institution would be expected to be very low.

Although bank regulators have relied on capital ratios formally or informally for a very long time, they have not always used the ratios in the same way. For instance, in the days before explicit capital requirements, bank supervisors would use capital ratios as rules of thumb to gauge the adequacy of an institution's level of capital. There was no illusion that the simple ratios used (for example, capital to total assets or capital to deposits) could provide an accurate measure of the appropriate capital level for a bank, but large deviations of actual capital ratios from supervisory benchmarks suggested the need for further scrutiny. When capital ratios were introduced formally in regulation in 1981, they were applied in a different way. The regulatory requirement set a minimum level of capital that the institution had to hold. The degree to which the requirement was binding depended significantly on the type of institution because, then as now, there was substantial diversity among banking institutions (Gilbert, Stone, and Trebing; 1985). Several classes of institutions were initially defined and accorded different treatment by the regulation. Basically, the requirements were most binding for less than a couple of dozen large banks, whereas smaller banks were generally already in compliance with the more stringent requirements (Berger, Herring, Giorgio, 1995).

The Basel Accord of 1988 attempted to deal with the diversity in institutional activities by applying different credit risk weights to different positions and by including in the base for the capital ratio a measure of the off-balance-sheet exposures of the bank. Despite these calibrations, the intent was not to determine an exact appropriate level of capital for the bank, but rather to provide a more flexible way of determining the minimum required level (Basel Committee on Banking Supervision 1988). Risk weighting effectively requires financial institutions to charge more capital for riskier assets, discouraging them from holding risky assets. By responding to the risk-reducing incentives, banks can increase the risk-weighted ratio without raising capital. On the other hand, failure to respond would result in a low risk-weighted ratio. Thus, if risk weights accurately reflect the riskiness of assets, the risk-weighted ratio should better distinguish between risky and safe banks and should be a more effective predictor of bank failure than simple ratios. Inaccuracy is unavoidable, however. Because each loan is unique, it is difficult to evaluate the credit risk of bank assets. In addition, the business of banking is subject to significant sources of risk other than credit risk, such as interest rate risk, operational risk, and reputational risk. Weighting assets can weaken the relationship between the capital ratio and these other risks - operational risk in particular. Furthermore, the financial sector is so dynamic that new products are introduced continuously. Even a welldesigned risk-weighting scheme may soon become obsolete as new instruments provide means of economizing on regulatory capital (Cole and Gunther, 1995). Considering these difficulties, it is not surprising that a singular measure such as the capital ratio fails to capture the totality of risk facing a bank. Tarullo (2009) presents ample evidence of the costs of relying too heavily on capital requirements for effective bank regulation.

\section{METHODOLOGY}

To assess the predictive efficacy of the Tier One Risk-Based Capital Ratio, the Pearson Correlation Coefficient is applied to the relationship between the capital ratio and the charge-off ratio, the ultimate indictor of loan failure. All 429 Minnesota-chartered banks, first-quarter, 2009, are utilized.

\section{FINDINGS}

A Pearson correlation coefficient of -.3507 corroborates the negative relationship expected between the level of bank capital and the level of charged off loans. However, this relationship is rather weak, suggesting that while the capital ratio may presage financial difficulties, it is by no means a tell-tale of imminent trouble. In fact, of the 429 banks in this study, only five had capital ratios below 6\%, yet twenty had charge-off ratios at 3\% or higher. 


\section{CONCLUSION}

Regulated bank capital may result in capital structure suboptimization. Banks are subject to significant information asymmetry. This, coupled with relatively low cost insured liabilities, suggests a relatively high cost for bank capital. Further regulatory constraints may only exacerbate this situation and bank capital may not be a reliable harbinger of loan charge-offs. Reliance on bank capital levels as a primary tool of risk assessment, in both an academic and professional context, is short cited. A more circumspect risk assessment, with greater public disclosure of a bank's CAMELS condition and a shift in attention from sources to uses of bank funds, would better serve the interests of bank managers, shareholders, and regulators.

\section{AUTHOR INFORMATION}

Charles Corcoran - I am a professor at the University of Wisconsin - River Falls. I joined UW-RF in the fall of 1988. I received a Ph.D. and MBA from the University of Minnesota. I have an undergraduate degree in finance from Georgetown University. I am also a CFA, Chartered Financial Analyst. I have taught virtually every course in our finance curriculum. I also teach an on-line finance course with University of Wisconsin system. My recent research interests relate to personal finance issues, such as the mean reversion of closed end mutual funds and the growing popularity of payday lending. Over the past several years, I have had many contract appointments (curriculum content, exam writing, exam grading) with the CFA Institute. This past summer, I worked with the fixed income component to the Level I exam.

\section{REFERENCES}

1. Basel Committee on Banking Supervision. 1988. "International Convergence of Capital Measurement and Capital Standards.” Bank for International Settlements, June-July, 1999.

2. Berger, Allen N., Richard J. Herring, and Giorgio P. Szegö. 1995. "The Role of Capital in Financial Institutions." Journal of Banking and Finance 19 (June): 393-430.

3. Cole, Rebel A., and Jeffery W. Gunther. 1995. "Separating the Likelihood and Timing of Bank Failure." Journal of Banking and Finance 19, no. 6 (September): 1073-89.

4. $\quad$ FDIC web site, June-August, 2009

5. Devereux, Michael and Schiantarelli, Fabio, "Investment, Financial Factors, and Cash and Investment, University of Chicago Press, Chicago, 1990.

6. Eden, Benjamin, and Jovanovic, Boyan, 1994. Asymmetric information and the excess volatility of stock prices. Economic Inquiry, (April).

7. Federal Deposit Insurance Corporation, 2009, web site (July-August).

8. Fazzari, Steven, and Hubbard, Glenn, 1988. Financing Constraints for Corporate Investment,” Brookings Papers on Economic Activity, 1988, 14 1-195.

9. $\quad$ Gilbert, Alton, Courtenay Stone, and Michael Trebing. 1985. "The New Bank Capital Adequacy Standards.” Federal Reserve Bank of St. Louis Review 67, no. 5 (May): 12-20.

10. Madura, Jeff, Financial Markets and Institutions, Thoson-Soutwestern, 2007.

11. Mitchell, Wesley C. 1909. "The Decline in the Ratio of Banking Capital to Liabilities." Quarterly Journal of Economics 23 (August): 697-713.

12. Modigliani, F. and M. Miller (1958): "The Cost of Capital, Corporate Finance, and the Theory of

13. Investment," American Economic Review 48, 261-297.

14. Tarullo, Daniel K., Banking on Basel: The Future of International Financial Regulation, Peterson Institute for International Economics, 2009.

15. Ting, Christopher, Determinants of Intra-Day Stock Price Change and Asymmetric Information, March 11, 2005). Available at SSRN: http://ssrn.com/abstract=683650 